\title{
Dental trauma clinically mimicking single central incisor syndrome
}

\author{
Traumatismo dentário mimetizando clinicamente a síndrome \\ do incisivo central único
}

\begin{abstract}
Purpose: This paper presents a clinical case in which a patient was missing a median central incisor due to trauma but was referred for orthodontic treatment because of suspicions of solitary median maxillary central incisor (SMMCI) syndrome.

Case description: A 12-year-old female patient visited the clinic with concerns about the appearance of her teeth. An oral examination revealed the presence of a single central incisor that was located on the midline and was adjacent to the maxillary lateral incisors. The patient reported two episodes of dental avulsion (of teeth 11 and 21) that had occurred approximately four years earlier. Tooth 11 was replanted; however, it was subsequently extracted due to pain. A panoramic radiograph and cephalometric analysis revealed a history of unsuccessful root canal treatment on tooth 21 , a straight profile and symmetrical facial features. Tooth 21 was extracted, followed by the traction of the maxillary teeth in the mesial direction and the esthetic transformation of the lateral incisors into central incisors and the canines into lateral incisors.
\end{abstract}

Conclusion: Dental trauma followed by tooth loss may mimic solitary median maxillary central incisor syndrome.

Keywords: Solitary median maxillary central incisor syndrome; traumatism

\section{Resumo}

Objetivo: Apresentar um caso clínico de ausência de um incisivo central perdido por traumatismo e encaminhado ao ortodontista com suspeita de apresentar síndrome do incisivo central único (SMMCI).

Descrição do caso: Paciente gênero feminino, 12 anos com queixa da aparência de seus dentes. Ao exame intrabucal observou-se a presença de um incisivo central único localizado na linha média sem espaçamentos em relação aos incisivos laterais superiores. A paciente relatou dois episódios de avulsão dos dentes 11 e 21 , cerca de quatro anos antes. No entanto, devido a sintomas de dor após reimplante, o dente 11 foi extraído. A radiografia panorâmica e análise cefalométrica revelou a presença de tratamento insatisfatório do canal radicular do dente 21, um perfil reto e padrão de equilíbrio facial. Extração do dente 21 foi realizada, com tração posterior dos dentes superiores na direção mesial, seguido pela transformação estética dos incisivos laterais em incisivos centrais e dos caninos em incisivos laterais.

Conclusão: $O$ traumatismo seguido de perda dentária pode mimetizar um quadro de síndrome do incisivo central único.

Palavras-chave: Síndrome do incisivo central único; traumatismo

\author{
Rafaela Nogueira Moreira a \\ Flaviana Dornela Verli b \\ Sandra Aparecida Marinho ${ }^{c}$ \\ Conceição Eunice Canuto ${ }^{d}$ \\ Altair Borges Costad \\ Leandro Silva Marques ${ }^{\text {e }}$
}

a Graduate Program in Dentistry, Federal University of Vales do Jequitinhonha e Mucuri, Diamantina, MG, Brazil

b Department of Pathology, Federal University of Vales do Jequitinhonha e Mucuri, Diamantina, MG, Brazil

c Department of Pathology, School of Dentistry, Universidade Estadual da Paraíba (UEPB), Araruna, PB, Brazil

d Department of Ortodontics, Universidade Federal dos Vales do Jequitinhonha e Mucuri, Diamantina, MG, Brazil

e Department of Orthodontics, School of Dentistry, University of Vale do Rio Verde (UNINCOR), Três Corações, MG, Brazil

\author{
Correspondence: \\ Rafaela Nogueira Moreira \\ Rua da Glória, 187 - Sala 22, Campus I \\ Diamantina, MG - Brazil \\ E-mail: rafismm@yahoo.com.br \\ Received: July 14, 2011 \\ Accepted: January 13, 2012
}

Conflict of Interests: The authors state that there are no financial and personal conflicts of interest that could have inappropriately influenced their work.

Copyright: (C) 2011 Moreira et al.; licensee EDIPUCRS. This is an Open Access article distributed under the terms of the Creative Commons AttributionNoncommercial-No Derivative Works 3.0 Unported License. 


\section{Introduction}

The presence of a solitary incisor positioned on the midline may be related to premature tooth loss due to trauma, hypodontia or, more rarely, solitary median maxillary central incisor (SMMCI) syndrome (1-6). SMMCI syndrome is rare, affecting 1:50,000 live births, and is more common among females $(1,6,7)$. Although its etiology remains uncertain, SMMCI syndrome may be related to chromosomal alterations, mutations in the SHH gene or holoprosencephaly, a severe condition that affects the midline development of the brain and face $(1,5,6,8)$.

Orthodontists often diagnose cases of SMMCI syndrome that have no obvious cause. Referral for the appropriate genetic testing and counseling should be considered for such patients (1). Moreover, because dental trauma may clinically mimic SMMCI syndrome, a particularly thorough documentation of the patient's history is necessary. Although there has been a report that traumatism may be confused with SMMCI syndrome (1), no clinical cases characterized by such a misunderstanding have been published.

This paper presents a clinical case in which the patient was missing a median central incisor because of trauma but was sent for orthodontic treatment due to suspicions of SMMCI syndrome.

\section{Description of the case}

A 12-year-old female patient who visited the clinic of the Specialization Course in Orthodontics had been diagnosed with SMMCI syndrome and had concerns about the appearance of her teeth (Fig. 1). An oral examination revealed the presence of a single central incisor located on the midline that was adjacent to the maxillary lateral incisors. Crowding of the mandibular incisors and a Class II malocclusion were also observed. A panoramic radiograph and cephalometric analysis revealed a history of unsatisfactory root canal treatment on tooth 21 , a straight profile and symmetrical facial features.

While documenting her dental history, the patient reported two episodes of trauma that had occurred approximately four years earlier. The first trauma caused the avulsion of teeth 11 and 21, which were replanted in their alveoli following root canal treatment. The second trauma occurred one year after the first and involved another avulsion of tooth 11, which was replanted but later extracted because of pain.

The aims of the treatment described in the present report were to restore the patient's esthetics with regard to the solitary central incisor and to correct the malocclusion and the crowding of the mandibular incisors. Two treatment options were presented to the patient's guardian. The first consisted of the extraction of tooth 21 , the traction of the maxillary teeth in the mesial direction, the esthetic transformation of the lateral incisors into central incisors and the canines into lateral incisors and the extraction of tooth 35 to correct the mandibular arch crowding. The second option comprised the extraction of the maxillary first premolars; the distal

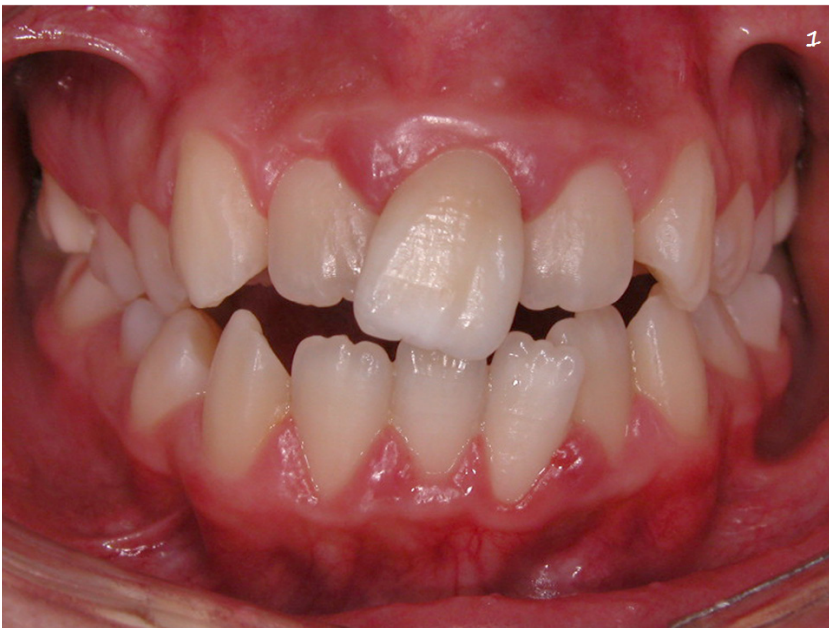

Fig. 1. Intraoral characteristics of the patient show the presence of a solitary incisor positioned on the midline, which clinically mimics central incisor syndrome.

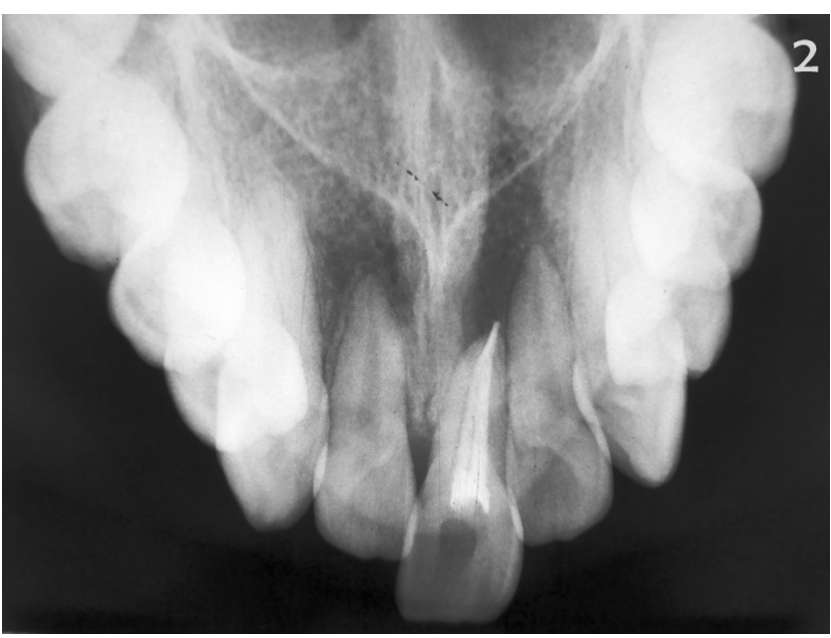

Fig. 2. Maxillary occlusal radiography revealed a history of unsuccessful root canal treatment on tooth 21 and the absence of tooth 11 .

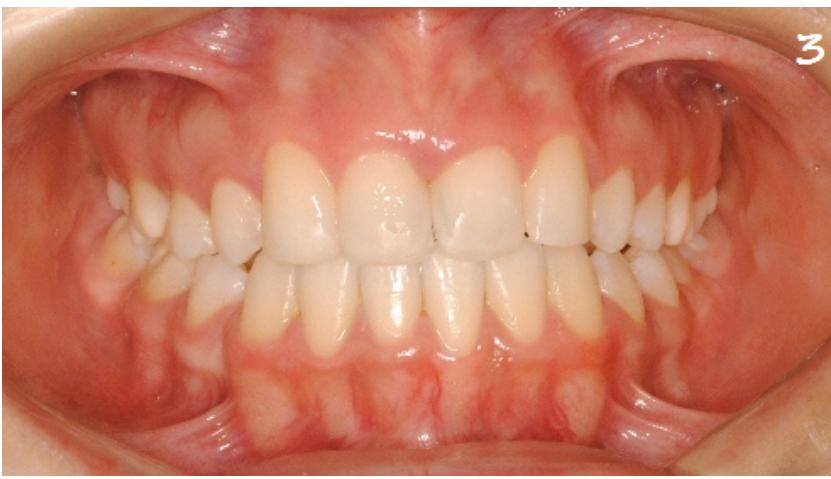

Fig. 3. Final appearance after orthodontic traction and the esthetic transformation of the maxillary canines into lateral incisors. 
movement of the canines, lateral incisors and solitary central incisor; and the placement of a dental implant to restore tooth 21. Due to the patient's history of unsuccessful root canal treatment, the presence of a periapical lesion on tooth 21 and financial constraints, the first option was chosen.

\section{Discussion}

The clinical case described here involved a solitary central incisor located on the midline, which is one of the characteristics of SMMCI syndrome (6). Although this syndrome can occur in both dentitions in an isolated fashion, it is often associated with midline defects, hypophysis dysfunction, holoprosencephaly (HPE) and systemic alterations, such as cardiac, metabolic and renal disorders (1,2-6,9-12).

Although HPE is commonly associated with SMMCI syndrome, the patient in the present case did not exhibit any of the characteristics of this condition, such as cleft lip/palate, agenesis of the premaxilla, ocular hypotelorism, a flat nose or microcephaly (1). Whereas all cases of HPE are associated with SMMCI syndrome, the inverse is not true (9). The diagnosis of such an association entails important implications for the patient's physical and mental development, as well as an elevated risk of manifestation in family members. Therefore, it is critical that midline defects in dental development are thoroughly investigated (13).

Although the patient in the present case had a solitary incisor located on the midline, she exhibited no other characteristics of SMMCI syndrome, such as an absent maxillary labial frenulum, incisive papilla or intermaxillary suture; a bow-shaped maxillary lip with a short, poorly defined filter; or microcephaly $(1,2-4,6,9,11,12)$. Moreover, the patient reported a history of dental trauma involving the avulsion of a maxillary central incisor, thereby precluding a diagnosis of SMMCI syndrome. The mesial movement of tooth 21 and the closure of the spaces between this tooth and the lateral incisors were likely due to the relatively long time (approximately 3 years) between the avulsion and the orthodontic consultation, by which time the condition clinically mimicked SMMCI syndrome. This case demonstrates the importance of a detailed patient history in establishing the differential diagnosis between SMMCI syndrome and dental trauma.

There are few published reports of orthodontic treatment for patients with SMMCI syndrome (10). In general, no treatment should be performed on the primary dentition (14). The treatment of the permanent dentition varies depending on the characteristics of the malocclusion; it essentially consists of either closing or opening spaces to enable oral rehabilitation $(6,15)$. Although the present case did not involve this syndrome, the treatment options were similar to those for SMMCI syndrome. The treatment that was undertaken consisted of the removal of the solitary central incisor, orthodontic traction to close the spaces and esthetic recontouring.

When SMMCI syndrome is suspected, a multidisciplinary approach is essential. In addition to orthodontic treatment to restore function and esthetics, a medical consultation and a referral to a geneticist are necessary because there may be systemic impairments and clinical manifestations in the patient's oral structures. Thus, the diagnostic participation of a dentist is of utmost importance in cases of suspected SMMCI syndrome because only a dentist can eliminate the possibility of this syndrome through a discerning clinical and radiographic analysis of the oral cavity.

\section{Conclusions}

Dental trauma followed by tooth loss may mimic solitary median maxillary central incisor syndrome. Because this syndrome causes both oral and systemic alterations, a thorough patient history and a joint evaluation by both a dentist and physician are necessary. Through clinical and radiographic examinations, the dentist can assist the physician in the diagnosis. Genetic testing can confirm the diagnosis and verify the systemic condition of the patient. 2008;35:16-9.

2. Hall RK, Bankier A, Aldred MJ, Kan K, Lucas JO, Perks AG. Solitary median maxillary central incisor, short stature, choanal atresia/midnasal stenosis (SMMCl) syndrome. Oral Surg Oral Med Oral Pathol Oral Radiol Endod 1997;84:651-62.

3. Yassin OM, El-Tal YM. Solitary maxillary central incisor in the midline associated with systemic disorders. Oral Surg Oral Med Oral Pathol Oral Radiol Endod 1998;85: 548-51.

4. Kjaer I, Becktor KB, Lisson J, Gormsen C, Russell BG. Face, palate, and craniofacial morphology in patients with a solytary median maxillary central incisor. Eur J Orthod $2001 ; 23: 63-73$.

5. Garavelli L, Zanacca C, Caselli G, Banchini G, Dubourg C, David V et al. Solitary median maxillary central incisor syndrome: clinical case with a novel mutation of sonic hedgehog. Am J Med Genet 2004;127:93-5.

6. Hall RK. Solitary median maxillary central incisor (SMMCI) syndrome. Orphanet J Rare Dis $2006 ; 9: 1: 12$. 
7. Machado E, Machado P, Grehs B, Grehs RA. Solitary median maxillary central incisor syndrome: case report. Dental Press J Orthod 2010;15:55-61.

8. Nanni L, Ming JE, Du Y, Hall RK, Aldred M, Bankier A, Muenke M. SHH mutation is associated with solitary median maxillary central incisor: a study of 13 patients and review of the literature. Am J Med Genet 2001;102:1-10.

9. Blackmore K, Wynne DM. A case of solitary median maxillary central incisor (SMMCI) syndrome with bilateral pyriform aperture stenosis and choanal atresia. Int J Pediatr Otorhinolaryngol 2010;74:967-9.

10. Bolan M, Derech CD, Corrêa M, Ribeiro GL, Almeida IC. Palatal expansion in a patient with solitary median maxillary central incisor syndrome. Am J Orthod Dentofacial Orthop 2010;138:493-7.

11. Richieri-Costa A, Ribeiro LA. Single maxillary central incisor, holoprosencephaly, and holoprosencephaly-like phenotype. Am J Med Genet 2006;40:2594-7.

12. Lo FS, Lee YJ, Lin SP, Shen EY, Huang JK, Lee KS. Solitary maxillary central incisor and congenital nasal pyriform aperture stenosis. Eur J Pediatr 1998;157:39-44.

13. DiBiase AT, Elcock C, Smith RN, Brook AH. A new technique for symmetry determination in tooth morphology using image analysis: application in the diagnosis of solitary maxillary median central incisor. Arch Oral Biol 2006;51:870-5.

14. Hall RK. Solitary median maxillary central incisor (SMMCI) syndrome. Orphanet Encyclopedia 2006;1:12.

15. Cho SY, Drummond BK. Solitary median maxillary central incisor and normal stature: a report of three cases. Int J Paediatr Dent 2006;16:128-34. 